\title{
Iron deficiency anemia in the elderly
}

\author{
Indra Kurniawan
}

Pangkalbalam Public Health Centre \& Bhakti Wara Hospital, Pangkalpinang, Bangka Belitung Archipelago, Indonesia

\begin{abstract}
Abstrak
Jumlah kaum lanjut usia (lansia) di seluruh dunia mengalami pertumbuhan dengan pesat. Anemia merupakan masalah hematologi yang paling utama pada lansia. Namun, anemia sebaiknya tidak dianggap sebagai konsekuensi penuaan yang tidak dapat dihindari. Anemia pada lansia menandakan adanya suatu penyakit yang mendasari. Anemia Defisiensi Besi (ADB) merupakan salah satu penyebab utama anemia pada lansia. ADB pada lansia menyebabkan terjadinya gejala-gejala yang tidak spesifik. Diagnosis ADB biasanya didasarkan pada hasil laboratorium. Oleh karena itu, penggunaan berbagai pemeriksaan laboratorium memegang peranan penting di dalam penegakkan diagnosis $A D B$. Adanya $A D B$ pada lansia biasanya berhubungan dengan terjadinya suatu kelainan gastrointestinal. Maka pada semua pasien dengan ADB perlu dilakukan evaluasi gastrointestinal kecuali pada mereka yang mempunyai riwayat perdarahan non gastrointestinal yang bermakna secara klinis. Lansia yang mengalami ADB perlu mendapat supplementasi besi, baik untuk mengkoreksi anemia maupun untuk memperbaiki cadangan besi tubuh. Selain itu, juga harus dilakukan tatalaksana terhadap penyakit yang mendasari untuk mencegah kehilangan besi lebih lanjut. (Med J Indones 2011; 20:71-7)
\end{abstract}

\begin{abstract}
The numbers of older people in the world have been growing rapidly. Anemia is the most common hematologic problem encountered in older adults. However, anemia should not be accepted as an inevitable consequence of aging. Anemia in the elderly signifies an underlying disease. Iron Deficiency Anemia (IDA) is being one of the most common causes of anemia in older people. IDA in the elderly is often associated with such non specific symptoms. The diagnosis of IDA is typically based on laboratory results. Hence, the utilization of the various laboratory tests plays an important role for the diagnosis of IDA. The presence of IDA in the elderly is usually related with gastrointestinal disorders. Thus, gastrointestinal evaluation should be contemplated in all patients with IDA unless there is a history of clinically important non gastrointestinal blood loss. Older people with IDA should have iron supplementation both to correct anemia and to replenish body iron stores. However, the underlying cause should always be treated to prevent further iron loss. (Med J Indones 2011; 20:71-7)
\end{abstract}

Key words: anemia, elderly, gastrointestinal, iron deficiency

Anemiais definedas a reductionin thenumberofcirculating red blood cells, or the hemoglobin concentration in the blood. The World Health Organization (WHO) defined it as a hemoglobin $(\mathrm{Hb})$ level $<13 \mathrm{~g} / \mathrm{dL}$ in men and $<12 \mathrm{~g} / \mathrm{dL}$ in women. Anemia is extremely frequent in elderly persons, defined in this article as those aged 65 years and older. A recent review of studies of anemia in elderly patients (2008) confirms that anemia affects 1 in every 7 or 8 older people living in the community. ${ }^{1,2}$

Nowadays, anemia is considered to be an important health problem among the elderly. With advancing age, there is a progressive and apparently physiological decrement of marrow hematopoesis. However, anemia in the elderly is due to disease and should never be considered as a normal physiological response to ageing. ${ }^{1,2}$

The causes of anemia in the elderly are diverse, with anemia of chronic disease and iron deficiency anemia being the most common causes. In community studies, Correspondence email to:indra_kurniawan@windowslive.com
Iron Deficiency Anemia (IDA) outranks the anemia of chronic disorders in prevalence, but the reverse is encountered in hospital practice. The diagnosis of IDA is important because proper iron therapy can improve the symptoms, and investigations may help in detecting an occult gastrointestinal pathology such as malignancy. $1,3,4$

\section{AGE-ASSOCIATED CHANGES IN THE HEMATOPOIETIC SYSTEM}

The bone marrow is the site of production for blood cells, such as circulating RBCs, granulocytes, and platelets. As aging proceeds, the marrow becomes increasingly localized to the axial skeleton. However, in the nondiseased elderly, the total number of marrow cells in the body is not decreased; it is similar to that of healthy young adults. Consequently, clinical examination of the marrow of older persons does not differ from that of normal young adults. The prevalence of anemia is 
increased in populations of community-dwelling, clinic visiting, and hospitalized elderly. However, anemia is not a consequence of aging. This supports the concept that older persons develop anemia due to underlying disease. ${ }^{5}$

\section{ETIOLOGY}

In the absence of any history of hemorrhage, iron deficiency anemia in older people is sometimes related to diet, but is usually a result of digestive disorder. Focusing on digestive disorders, the etiology of IDA of gastrointestinal origin can be divided into two groups: situations with increased loss of iron and those with decreased iron absorption. In the former, there could be a hidden bleeding, which might be more difficult to diagnose. Common causes include NSAID use, colonic cancer or polyp, gastric cancer, angiodysplasia, and inflammatory bowel disease. Rare causes include previous gastrectomy, intestinal teleangiectasia, lymphoma, leiomyoma and other small bowel tumour. The possible existence of a malignancy as the source of anemia, which leads to early completion of endoscopic examinations is a great concern. ${ }^{3,6-8}$

In the second category of etiology, reduced iron absorption can be caused by celiac disease, atrophic gastritis, and postsurgical status (gastrectomy, intestinal resection). In a study on patients referred to gastroenterologists because of IDA, celiac disease was the diagnosis in at least $2-3 \%$ of cases. Microscopic alterations in the duodenal mucosa in non-treated celiac disease will lead to a refractory condition in oral iron treatment. Gastroscopy with biopsy allowed detection of gastritis with or without H.pylori. The positivity of autoantibodies (anti-intrinsic factor or anti-parietal cell) supports the diagnosis of autoimmune atrophic gastritis. A recent meta-analysis concluded that the infection of H.pylori is associated with depleted iron deposits. The mechanism is not clear, but it appears to involve gastrointestinal blood loss, diminished iron absorption from the diet, and increased consumption of iron by the bacteria. ${ }^{6,9}$

\section{CLINICAL MANIFESTATION}

The clinical presentation of IDA depends on the degree of anemia, the speed of onset, the underlying cause, and the presence of comorbid conditions. IDA in the elderly is often associated with such nonspecific symptoms as general weakness, fatigue, functional decline, irritability, poor concentration and headache. Sometimes, IDA causes no symptoms (asymptomatic) and could be found only by laboratory survey. Although the impact of IDA on the quality of life of the subject is high, they often get used to their symptoms and these are assumed as normal. The patient becomes aware of an improvement only when the symptoms disappear. ${ }^{4,10,11}$

Older people with IDA might have alopecia, atrophy of lingual papillae, or dry mouth due to loss of salivation. These changes were caused by reduction of iron-containing enzymes in the epithelia and the gastrointestinal tract. Some older people could have other signs, such as cheilosis (fissures at the corners of the mouth) and koilonychia (spooning of the fingernails). The presence of these signs suggests that there might be an advanced tissue iron deficiency. Physical examination might be normal or show pallor of varying intensity. Besides that, there might be a systolic murmur in cardiac auscultation. ${ }^{4,10-12}$

\section{LABORATORY FINDINGS}

The diagnosis of IDA is typically based on laboratory results. There are various measurements of iron status. No single measurement is ideal for all clinical circumstances, as all are affected by confounding factors. Hence, the utilization of the various laboratory tests for the diagnosis of IDA is required.

\section{Complete blood count}

The World Health Organization (WHO) defines anemia as the decline in blood hemoglobin to a concentration below $13 \mathrm{~g} / \mathrm{dl}$ in men and $12 \mathrm{~g} / \mathrm{dl}$ in women. The diagnosis of anemia needs complete blood count examination, including a measure of the mean corpuscular volume (MCV). In this way, the anemias can be characterized morphologically as normocytic, microcytic, or macrocytic. Faced with microcytic anemia, there are four main diagnostic possibilities include iron deficiency anemia (IDA), thalassemia, anemia of chronic disorders, and sideroblastic anemia. The next step in diagnosis should be directed toward confirmation or exclusion of IDA. ${ }^{5,10,12}$

2. Serum iron (SI) and total iron binding capacity (TIBC)

The SI level represents the amount of circulating iron bound to transferrin. The TIBC is an indirect measure of the circulating transferrin. The SI and TIBC give a measure of the iron supply to the tissues. In normal subjects, SI shows a diurnal rhythm, with values being lower in the morning 
than in the evening. In iron deficiency, however, values stabilize at low levels respectively. A low SI $(<10 \mu \mathrm{mol} / \mathrm{l})$ with increase in TIBC $(>70 \mu \mathrm{mol} / \mathrm{l})$ is characteristic of iron deficiency. A serum transferrin saturation $(\mathrm{SI} / \mathrm{TIBC} \times 100)$ that is persistently less than $15 \%$ is insufficient to support normal erythropoiesis, indicates iron deficiency states. ${ }^{7,13,14}$

\section{Serum ferritin}

Free iron is toxic to the cells, and the body has established a set of protective mechanisms to bind iron in various tissue compartments. Within cells, iron is stored complexed to protein as ferritin. Apoferritin binds to free ferrous iron and stores it in the ferric state. Iron in ferritin can be extracted for release by the RE cells. In normal conditions, the serum ferritin level reflects total body iron stores. Thus, the serum ferritin level is the most convenient laboratory test to estimate iron stores. ${ }^{13}$

The normal value for ferritin varies according to age of the individual. Serum ferritin level tends to rise with aging. In adults, a serum ferritin concentration $<15 \mu \mathrm{g} / \mathrm{L}$ is diagnostic of iron deficiency. However, in the elderly, the diagnosis of IDA is highly likely in those with ferritin levels of up to $45 \mu \mathrm{g} / \mathrm{L}$. A low serum ferritin level always indicates iron deficiency, but normal value does not exclude this because ferritin synthesis is influenced by factors other than iron. It also acts as an acute-phase reactant in many inflammatory diseases. Iron deficiency is highly unlikely if the serum ferritin concentration is $>100$ $\mu \mathrm{g} / \mathrm{L} .7,13,14$

\section{Evaluation of bone marrow iron stores}

Bone marrow aspiration and staining for iron (Prussian blue stain) provides a definite diagnosis of IDA. It is considered to be the standard for assessing iron status. However, in addition to storage iron, the marrow iron stain provides information about the effective delivery of iron to developing erythroblasts. Normally, when the marrow smear is stained for iron, $20-40 \%$ of developing erythroblast will have visible ferritin granules in their eythoplasm. This represents iron in excess of that needed for hemoglobin synthesis. In iron deficiency anemia, RE iron and erythroblast iron are absent. 7,13,14

\section{Red cell protoporphyrin}

Protoporphyrin is an intermediate in the pathway to heme synthesis. Under conditions in which heme synthesis is impaired, protoporphyrin accumulates within the red cell. This reflects an inadequate iron supply to erythroid precursors to support hemoglobin synthesis. Normal values are $<30 \mathrm{~g} / \mathrm{dL}$ of red cells. Concentrations greater than the normal upper limit of $80 \mathrm{~g} / \mathrm{dL}$ hemoglobin therefore indicate iron deficiency. Protoporphyrin levels may also increase in patients with sideroblastic anaemias and lead poisoning. Convenient analysers measure zinc protoporphyrin - the form in which most of the protoporphyrin exists in iron deficiency. ${ }^{13,14}$ Evaluation of iron status using the Zinc Protoporphyrin /Heme $(\mathrm{ZPP} / \mathrm{H})$ ratio is another diagnostic indicator of IDA diagnostic of early iron depletion. The $\mathrm{ZPP} / \mathrm{H}$ ratio reflects iron status in the bone marrow during the formation of $\mathrm{Hb}$. When iron supply is diminished, Zn utilization increases resulting in a high $\mathrm{ZPP} / \mathrm{H}$ ratio. Das and Philip compared the utility of $\mathrm{ZPP} / \mathrm{H}$ ratio as a diagnostic measure of IDA with bone marrow iron store aspirates. They concluded that $\mathrm{ZPP} / \mathrm{H}$ was reliable in reflecting the bone marrow iron status except in the pre-latent phase of iron deficiency. ${ }^{15}$

\section{Serum levels of transferrin receptor protein}

Serum transferrin receptor (sTfR) reflects erythropoesis and inversely the amount of iron available for erythropoiesis. STfR levels increase in the absence of storage iron (absolute iron deficiency). sTfRs can contribute significantly to the detection of IDA. Chang et al. compared the utility of serum sTfR levels and serum ferritin to bone marrow iron stores in identifying IDA. They concluded that elevated sTfR levels were found to be the most sensitive marker for the detection of absent bone marrow iron $(100 \%)$. This laboratory test is becoming increasingly available and, along with the serum ferritin, has been proposed to identifying IDA. ${ }^{13-15}$

\section{INVESTIGATION}

The underlying cause of IDA should always be investigated before treatment is begun, because in many cases it is correctable. A study reported that in most patients, the treatment of IDA will not be effective if a cause for IDA is not found.

\section{History}

Poor iron deficient diets are sometimes found and a dietary history should be taken to identify poor iron intake. The use of aspirin and NSAID should be noted and these drugs should be stopped when the clinical indication is weak or other choices are available. Family history of IDA (which may indicate inherited disorders 
of iron absorption), hematologic disorders (e.g. thalassaemia), telangiectasia and bleeding disorders should be sought. A history of blood donation should be obtained. The presence of one or more of these factors in the history need further investigation. ${ }^{3,10,16}$

\section{Examination}

Examination is usually non contributory to identify IDA but may reveal a relevant abdominal mass or cutaneous signs of rare causes of gastrointestinal blood loss (e.g. Peutz-Jeghers syndrome and hereditary haemorrhagic telangiectasia). Rectal examination should beperformed. Analysis of urine is recommended in all patients with IDA, as approximately one third of patients with renal cell carcinoma will have anemia due to haematuria and haemosiderin deposition in the tumour. Further renal tract evaluation with ultrasound is recommended where suspicion of renal tract malignancy is strong, followed by IVU and/or CT scan as necessary. ${ }^{3,10,16}$

\section{Gastrointestinal evaluation}

Gastrointestinal evaluation should be contemplated in all patients with IDA unless there is a history of clinically important non gastrointestinal blood loss. A recent study has suggested that elderly patients with IDA should undergo gastrointestinal evaluation, irrespective of the hemoglobin level. In most patients, a dilemma will arise; is it necessary to perform a gastroscopy, a colonoscopy or both? And which one should be carried out first? In elderly patients, a colonoscopy is preferred to gastroscopy in determining the cause of IDA. It has been described that in the presence of a low ferritin value, the probability of finding any pathology at colonoscopy will be quadrupled. This supports the need for colonoscopy in the study of IDA. ${ }^{6,7,17,18}$

One study of elderly hospital inpatients (mean age 71 years) with IDA found a high incidence (16\%) of dual pathology when both the upper and lower gastrointestinal tracts were examined. That means it is necessary to perform both techniques, except in those cases in which celiac disease or a neoplasm is diagnosed in the initial examination. Gastrointestinal endoscopies (gastroscopy and colonoscopy) might be performed in the same session or sequentially, according to the clinical history. The combination of gastroscopy and colonoscopy is highly sensitive and specific for locating gastrointestinal lesions that produce anemia. ${ }^{6,7,17}$

However, a study described that the combination of both endoscopic techniques only determines $62 \%$ the final cause of anemia in patients with IDA. If examinations are normal, anemia is not severe and symptoms do not suggest significant disease, the next step might be clinical follow-up and oral iron treatment. Further reevaluation is needed in patients not responding to oral iron treatment, having severe anemia or suspected serious illness. Repeating the endoscopic studies is justified because a proportion of lesions might not be detected with conventional endoscopes for several reasons (e.g. incomplete exploration, poor preparation, misinterpretation of findings, inadequate biopsies of lesions, or just not seeing the lesion). ${ }^{6,16}$

In those cases in which repeated endoscopic examinations are all negative, small bowel should be investigated as the source of anemia. The recommended approach is capsule endoscopy or enteroscopy for cases in which it is necessary to apply a treatment or to obtain biopsies of lesions. Classical imaging studies of the small intestine (bowel through and enteroclysis) are much less sensitive for detecting lesions potentially causing anemia and have been reserved for those centres where the previous techniques are not available or contraindicated. ${ }^{6,16}$

H.pylori colonisation may impair iron uptake and increase iron loss thus leading to IDA. H.pylori should be sought if the examinations mentioned before are normal and eradicated if present. Mesenteric angiography is of limited use but may be of value in transfusion dependent IDA for demonstrating vascular malformations. On the other hand, diagnostic laparotomy with on-table endoscopy may be considered in cases which have defied diagnosis by other investigations. ${ }^{6,9,15,16}$

\section{MANAGEMENT}

Management of IDA entails treatment of the underlying cause and correction of the deficiency by iron supplementation. IDA in the elderly is commonly due to blood loss, so the location of the lesion must be identified and treated. ${ }^{7}$

\section{Oral iron therapy}

Oral iron therapy is usually adequate for most patients. Oral therapy is an efficient, well tolerated and cost effective to replenish iron stores. Ferrous sulphate is the drug of first choice for iron supplementation therapy. Other forms, ferrous gluconate and ferrous fumarates are effective alternatives. $200 \mathrm{mg}$ of ferrous sulphate 
contains $67 \mathrm{mg}$ of elemental iron. It is usual to give 100-200 mg of elemental iron each day. ${ }^{11,14,19}$

The side effects of oral iron, such as nausea, epigastric pain, diarrhea and constipation, are related to the amount of available iron they contain. If iron causes gastrointestinal symptoms, these can usually be ameliorated by reducing the dose, or taking the iron with food, but this also reduces the amount absorbed. Entericcoated and sustained-release preparations should not be used because of their reduced availability at the iron absorption sites in the duodenum and upper jejunum. ${ }^{11,14,19}$

The response to iron therapy varies, depending on the erythropoietin (EPO) stimulus and the rate of absorption. Typically, the reticulocyte count increases within 3 to 4 days after the initiation of iron therapy and reaches a peak at 10 days. As recovery continues, the microcytic erythroytes gradually replaced by the normocytic cell population. As a consequence, the red cell volume distribution width, which is usually raised in IDA, may show a further rise, reflecting active erythropoesis. The hemoglobin concentration should rise by $2 \mathrm{~g} / \mathrm{dl}$ after 3-4 weeks. A lack of response implies non compliance, continued blood loss, misdiagnosis or malabsorption. To replenish body iron stores, iron supplementation should be continued for 3-6 months after correction of anemia. 7,13,15

A recent study suggest that H.pylori infection and chronic gastritis are also responsible to refractory IDA which is non responsive to oral iron therapy. Chen and Luo evaluated the effects of H.pylori erradication on erythrocytic and iron parameters in $H$. pylori gastritis patients with IDA. They concluded that the eradication of $\mathrm{H}$. pylori is warranted to maximize oral iron therapy in the recovery from IDA. ${ }^{9,15}$

\section{Parenteral iron therapy}

Parenteral iron replacement should only be considered when there is intolerance to at least two oral preparations, non compliance, or gastrointestinal diseases which cause severe iron malabsorption (e.g. inflammatory bowel disease). It is also necessary when oral iron cannot keep pace with continuing hemorrhage. The safety of parenteral iron, particularly iron dextran, has been a concern, related to its adverse effects especially anaphylactic reaction. Nowadays, newer iron complexes are available, such as sodium ferric gluconate and iron sucrose, that have a much lower rate of adverse effects. ${ }^{7,13,14}$

There are three preparations of parenteral iron which are widely available. Iron dextran is given intravenously by slow injection or infusion. Iron sorbitol is given deep (to avoid skin staining) by intramuscular (i.m.) injection (50-100 mg of iron per day) but not intravenously. An iron -sucrose complex, is given by slow intravenous infusion or injection and is now considered to be the safest form. ${ }^{7,14,15}$

Parenteral iron is used to administer the total dose of iron required to correct the hemoglobin deficit and provide the patient with at least $500 \mathrm{mg}$ of iron stores. The amount of iron needed is calculated individually for each patient using the following formula: ${ }^{13}$

Body weight $(\mathrm{kg})$ x $2.3 \times$ ( 15 - patient's hemoglobin, $\mathrm{g} / \mathrm{dl})+500$ or $1000 \mathrm{mg}$ (for stores)

The anaphylactic reaction is a potential serious side effect of iron dextran. The factors correlated with anaphylactic reaction, such as history of multiple allergies or prior allergic reaction to dextran should be considered before giving parenteral iron therapy. A test dose should be given slowly, followed by close medical supervision of the rest of the infusion. Flushing, nausea, urticaria, shivering, general aches and pains, dyspnea and syncope are possible immediate adverse effects. Delayed reactions, including arthralgia, fever and lymphadenopathy, can persist for several days. To date, IDA patients with sensitivity to iron dextran have been safely treated with the newer preparations which less likely to cause anaphylactic reaction. ${ }^{13,14,15}$

Treating laten or mild iron deficiency in older people (low serum ferritin with normal hemoglobin level) could potentially be harmful and at present there is no clear evidence for benefit of iron replacement in such patients. Iron is a double-edged sword as iron excess is associated with increased free radical production. This condition is associated with an increased cancer risk and atherogenic effects of LDL that will lead to further disorders. ${ }^{7}$

\section{Red cell transfusion}

The role of erythrocyte transfusion in the management of IDA in older people is contentious. It is a potentially hazardous way to correct iron deficiency. The eryhtrocyte transfusion can be justified in elderly patients if the anemia is symptomatic and unresponsive to the treatment of underlying disease. ${ }^{7}$

Iron deficiency produces a chronic anemia that usually does not require immediate correction by transfusion. In chronic anemias transfusion should be based on patient's conditions. It should only be given in patients 
who need immediate correction such as cardiovascular instability associated with anemia (angina pectoris, myocardial infarction, congestive heart failure). It also can be given when the patient has a haematocrit $<26 \%$ or hemoglobin $<9 \mathrm{~g} / \mathrm{dl}$ preoperatively or before chemoterapy. It is more essential to establish the cause of anemia and treat the underlying disorder. ${ }^{7,13}$

The British Society for Haematology guidelines recommend erythrocyte transfusion in chronic anemias only if the anemia is life-threatening. Transfusions should aim to restore hemoglobin to a safe level, but not necessary to normal values. Iron treatment should follow transfusion to replenish iron stores. ${ }^{7}$

\section{Follow-up}

After reach the normal values, the hemoglobin concentration and red cell indices should be monitored at intervals. A study suggest three monthly intervals for one year, then again after a further year. Oral iron supplementation should be given if the hemoglobin or red cell indices fall below normal. Further investigation is only necessary if the hemoglobin and red cell indices could not be maintained in this way. In most patients, iron deficiency does not return to normal if the cause for IDA is not found. ${ }^{16}$

In conclusion, Anemia is common in older adults, but the anemia should not be correlated simply to the aging. The presence of anemia in the elderly signifies an underlying disease. Iron Deficiency Anemia (IDA) is one of the most common causes of anemia in older people. Like other anemias, the IDA often manifests with non specific symptoms. The diagnosis of IDA is made by laboratory testing. There are various measurements of iron status. No single measurement is ideal for all clinical circumstances. Hence, the evaluation of various laboratory tests is needed to provide the best assessment of IDA.

The underlying cause of IDA should always be investigated. In the absence of any history of hemorrhage, IDA in the elderly is usually associated with gastrointestinal disorders. A brief investigation should be performed to identify the underlying disease of IDA. Since gastrointestinal disorders are the most common causes of IDA in the elderly, evaluation of the gastrointestinal system should be considered as a priority. Gastrointestinal evaluation should be contemplated in all patients with IDA unless there is a history of clinically important non gastrointestinal blood loss.

IDAinolderpeopleshould bemanaged comprehensively. The aim of treatment should be to restore hemoglobin levels and red cell indices to normal, and replenish body iron stores. This can be achieved by correction of the deficiency with iron supplementation therapy. However, identification and treatment of the underlying cause is needed before treatment is begun, to prevent further iron loss. Follow up should be performed to evaluate the efficacy of treatment .If the target of therapy cannot be achieved, consideration should be given to further evaluation.

\section{REFERENCES}

1. Gaskell H, Derry S, Moore A, McQuay HJ. Prevalence of anaemia in older persons: systematic review. BMC Geriatrics. 2008;8:1-8.

2. Guralnik JM, Ershler WB, Schrier SL, Picozzi VJ. Anemia in the Elderly: A public health crisis in hematology. Hematology. 2005:528-32.

3. Ohta M. Management of anemia in the elderly. Japan Med Assoc J. 2009;52(4):219-22.

4. Kane RL, Ouslander JG, Abrass RB, Resnick B. Essentials of clinical geriatrics. $6^{\text {th }}$ ed. New York: McGraw Hill; 2009. p. 379-80.

5. Hensley JM. Anemia in the elderly. In: Soriano RP, Fernandez HM, Cassel CK, Leipzig RM. Fundamentals of geriatric medicine : A Case-Based Approach. $1^{\text {st }}$ ed. New York: Springer; 2007. p. 470-7.

6. Gisbert JP, Gomollon F. A guide to diagnosis of iron deficiency and iron deficiency anemia in digestive diseases. World J Gastroenterol. 2009;15(37): 4638-43.

7. Mukhopadhyay D, Mohanaruban K. Iron deficiency anaemia in older people : investigation, management and treatment. Age and Aging. 2002;31:87-91.

8. Ho CH, Yu YB, Wu PH. The prevalence of iron deficiency anemia and its clinical implications in patients with colorectal carcinoma. J Chin Med Assoc. 2008 ;71(3):119-22.

9. DuBois S, Kearney DJ. Iron-deficiency anemia and helycobacter pylori infection : A review of the evidence. Am J Gastroenterol. 2005;100:453-9.

10. Karnath BM. Anemia in the adult patient. Hospital Physician. 2004:32-6.

11. Landefeld CS, Palmer RM, Johnson MA, Johnston CB, Lyons WL. Current geriatric diagnosis and treatment. $1^{\text {st }}$ ed. New York: McGraw-Hill; 2004.

12. Steensma DP, Tefferi A. Anemia in the elderly: How should we define it, when does it matter, and what can be done. Mayo Clin Proc. 2007;82(8):958-66.

13. Fauci SA, Kasper DL, Longo DL, Braunwald E, Hauser SL, Jameson JL, et al. Harrison's Principles of Internal Medicine. $17^{\text {th }}$ ed. New York: McGraw-Hill; 2008.

14. Worwood M, Hoffband AV. Iron metabolism, iron deficiency, and disorders of haem synthesis. In: Hoffband AV, Catovsky D, Tuddenham EG. Postgraduate Haematology. $5^{\text {th }}$ ed. Massachusetts: Blackwell Publishing; 2005. p. 34-8.

15. Clark SF. Irondeficiency anemia: diagnosis and management. Current Opinion in Gastroenterology. 2009;25:122-8.

16. Goddard AF, James MW, Mcintyre AS, Scot BB. Guidelines for the management of iron deficiency anaemia. BSG Guidelines in gastroenterology. 2005:1-5. 
17. Gisbert JP, Gomollon F. Classification of anemia for gastroenterologists. World J Gastroenterol. 2009;15(37): 4627-37.

18. Smieja MJ, Cook DJ, Hunt DL, Ali MA, Guyatt GH. Recognizing and investigating iron-deficiency anemia in hospitalized elderly people. Can Med Assoc J. 1996;155(6):691-6.

19. Goldman L, Ausiello D. Cecil Medicine : An expert consult. $23^{\text {rd }}$ ed. Philadelphia: Saunders-Elsevier; 2008.

\section{ERRATUM}

In the article "The DiabCare Asia 2008 study - Outcomes on control and complications of type 2 diabetic patients in Indonesia", authors: Pradana Soewondo, Sidartawan Soegondo, Ketut Suastika, Agung Pranoto, Djoko W. Soeatmadji, Askandar Tjokroprawiro, published in MJI vol IX/4 2010, wrong numbers on pages 235, 236, 239, 240, 242, 243 have been presented. Reprints of the article with corrected numbers are available and can be requested from the corresponding authorSoewondo@yahoo.com or MJI secretariatmji@fk.ui.ac.id. 